neofilolog

Czasopismo Polskiego Towarzystwa Neofilologicznego

ISSN 1429-2173, elSSN 2545-3971, 2020, NR 55/1, 27-49

http://dx.doi.org/10.14746/n.2020.55.1.3

http://poltowneo.org/

Beata Peć

Uniwersytet Warszawski

https://orcid.org/0000-0002-5875-1312

beata.pec@uw.edu.pl

\title{
Interdyscyplinarna specyfika kształcenia nauczycieli języków obcych (ze szczególnym uwzględnieniem pedeutologii i glottodydaktyki)
}

The interdisciplinary nature of foreign language teacher education
(with particular emphasis on the pedeutology and glottodidactics)

The purpose of this paper is to present the interdisciplinary nature of foreign language teacher education both from a theoretical and empirical perspective - including findings from a research study which was conducted at the Institute of German Studies at the University of Warsaw. The article shows the diversity of approaches to teacher education and defines glottodidactics as the basic disciplines of foreign language teacher education, exposing the influence of these disciplines on each other. The article presents a sample interdisciplinary teacher training program and, based on the results of the author's own research, the opinions of students on this subject.

Keywords: foreign language teacher education, glottodidactics, pedeutology, interdisciplinarity

Słowa kluczowe: kształcenie nauczycieli języków obcych, glottodydaktyka, pedeutologia, interdyscyplinarność

\section{Wprowadzenie}

Obowiązujące obecnie Rozporządzenie M inistra Nauki i Szkolnictwa Wyższego z dnia 20 września 2018 r. w sprawie dziedzin nauki i dyscyplin naukowych 
oraz dyscyplin artystycznych ustala ich klasyfikację. W dziedzinie nauk humanistycznych wyodrębnia się jako dyscyplinę naukową m.in. językoznawstwo, natomiast w dziedzinie nauk społecznych m.in. takie dyscypliny jak: pedagogika, psychologia, nauki prawne, nauki o komunikacji społecznej i medialnej.

Analizując standardy kształcenia nauczycieli języków obcych na przestrzeni ostatnich dziesięcioleci, można stwierdzić, że nie tylko glottodydaktyka jako subdyscyplina językoznawstwa jest w nich uwzględniana. Coraz większe znaczenie zyskują także psychologia i pedagogika. Co więcej - w ramach osiągania efektów w zakresie zdobywania wiedzy, rozwijania umiejętności i nabywania postaw w procesie kształcenia nauczycieli bierze się też pod uwagę prawo oświatowe, emisję głosu czy medioznawstwo. W ramach samej psychologii czy pedagogiki również mamy do czynienia z wielością subdyscyplin. Wyodrębnia się na przykład psychologię rozwojową czy psychologię różnic indywidualnych oraz chociażby pedagogikę specjalną oraz aksjologię pedagogiczną. W obecnym czasie w każdej dziedzinie i dyscyplinie można znaleźć pierwiastki innych nauk.

Niniejszy artykuł ukazuje dwie główne dyscypliny naukowe jako wiodące w procesie kształcenia nauczycieli języków obcych: pedeutologię oraz glottodydaktykę. Te dwa filary stanowią fundament nauki o nauczycielu języków obcych, określonej w niniejszym artykule mianem glottopedeutologii, mieszcząc się zarówno w obszarze nauk humanistycznych, jak i społecznych. Celem artykułu jest analiza interdyscyplinarnej specyfiki kształcenia nauczycieli języków obcych w perspektywie teoretycznej i empirycznej. Punkt wyjścia rozważań stanowi teza, iż obecnie kształcenie języków obcych wyróżnia się interdyscyplinarną specyfiką. Rozpoczyna je wyodrębnienie pedeutologii i glottodydaktyki jako podstaw owych filarów badawczych oraz wyeksponowanie konieczności ich integracji w ramach tego procesu. Następnie na przykładzie studium przypadku kształcenia nauczycieli języków obcych w jednym z polskich instytutów neofilologicznych zostaną przedstawione specyficzne elementy kształcenia glottopedeutologicznego. W podsumowaniu zawarto wnioski i perspektywy badaw cze.

\section{Filar pierwszy: pedeutologia}

Termin pedeutologia pochodzi od greckich słów paideutes - nauczyciel oraz logos - słowo, nauczanie. Nauka ta, uznawana za subdyscyplinę pedagogiki (Kwiatkowska, 2008: 17 i nn.; Hofer, 2010: 185 i nn.), po raz pierwszy została wyróżniona w latach 30. XX wieku, a obecnie staje się coraz bardziej niezależna. W niedawnej przeszłości badano w jej zakresie takie zagadnienia jak problematyka osobowości nauczycieli, wybór zawodu i przygotowanie do niego, praca zawodowa, szkolenie i dalsze kształcenie nauczycieli, doskonalenie ich umiejętności. Kuźma (2009: 210) mówi o konieczności „prowadzenia 
Interdyscyplinarna specyfika kształcenia nauczycieli języków obcych...

kompleksowych badań wszystkich stadiów rozwoju zawodowego i pedagogicznego nauczycieli". W niniejszym artykule kładzie się akcent na przygotowanie merytoryczno-zawodowe przyszłych nauczycieli języków obcych podczas kształcenia akademickiego.

W rozwoju pedeutologii można wyróżnić trzy okresy: od koncentracji na humanistyczno-osobistej wartości samego nauczyciela oraz rozumieniu jego pracy jako powołania i rodzaju służby dla dziecka (czasy pedagogiki reform przełomu wieków XIX i XX), poprzez naukowo-technologiczną kontrolę procesu kształcenia uczących i postrzeganie rezultatów ich pracy jako zbioru zastosowanych metod i technik nauczania (w czasach zmiany poznawczej w XX wieku), aż po fazę krytycznej refleksji na temat wpływu edukacyjnego nauczyciela na ucznia (od przełomu XX i XXI wieku po dzień dzisiejszy).

Podejście humanistyczne w pedeutologii wynika z konsolidacji psychologii oraz pedagogiki humanistycznej - dyscyplin naukowych eksponujących odkrywanie swoich mocnych stron przez osobę zdobywającą kwalifikacje do nauczania oraz jej dążenie do osiągnięcia pełni rozwoju. Technologiczna orientacja procesu kształcenia nauczycieli oznacza trening metod, form, technik i strategii nauczania. Podejście funkcjonalne uwypukla zaś funkcjonalną analizę i świadomą refleksję kandydata do zawodu nauczycielskiego nad swoimi działaniami i zachowaniami oraz zaobserwowanymi zdarzeniami psychologiczno-pedagogiczno-dydaktycznymi (np. Kwiatkowska, 2008; Mizerek, 1999: 15 i nn.). Pomimo, że wymienione trzy orientacje kształcenia nauczycieli mają charakter historyczny (zob. Arends, 1994: 28-34), są uwzględniane we współczesnym i nowoczesnym kształceniu nauczycieli języków obcych (co ukazują również wyniki przedstawionych dalej badań; zob. 6).

Pedeutologia jako subdyscyplina pedagogiki czerpie przede wszystkim z wyników badań psychologicznych, samej pedagogiki, dydaktyki ogólnej oraz dydaktyki poszczególnych przedmiotów, a także z badań nad komunikowaniem się czy z kognitywistyki. U podstaw współczesnej naukowej refleksji pedagogicznej (a więc także pedeutologicznej) stoi częściowo psychologia atomistyczna (strukturalistyczna, a przede wszystkim funkcjonalna) i psychologia behawiorystyczna (z jej koncepcją wolności i godności człowieka), ale nade wszystko psychologia humanistyczna (akcentująca, wspomniane wyżej, dążenie do samourzeczywistnienia się, samodoskonalenia i samorealizacji) (zob. M atyjas, Ratajek, Trafiałek, 1997: 50-61). Nie można też nie wspomnieć o roli wyników badań empirycznych z zakresu nowoczesnej biopsychologii. W zakresie pedagogiki natomiast wyjątkowe znaczenie w badanym zakresie ma psychologizm pedagogiczny, w ramach którego można wyróżnić personalizm pedagogiczny, obejmujący m.in. teorie nowego wychowania Marii Montessori, Celestina Freinet'a, Janusza Korczaka czy Marii Grzegorzewskiej, a także 
pedagogikę humanistyczną (zob. Matyjas, Ratajek, Trafiałek 1997: 62-112). W odniesieniu do specyfiki kształcenia nauczycieli języków obcych należy w tym miejscu szczególnie podkreślić istotny związek pedeutologii i glottodydaktyki.

Według Malinowskiej (2008: 119), budowanie się świadomości nauczycielskiej w teraźniejszości jest m. in. wynikiem doświadczeń w przeszłości. Dlatego interdyscyplinarne kształcenie nauczycieli może posłużyć jako zaczątek dla późniejszego świadomego doskonalenia własnego warsztatu pracy przez przyszłego nauczyciela (w tym nauczyciela języków obcych), a sam proces zdobywania kwalifikacji ma być oparty na autoregulacji (Paris, Ayres, 1997: 29-41).

\section{Filar drugi: glottodydaktyka}

Glottodydaktyka jest przedstawiana tutaj jako drugi główny filar naukowy kształcenia nauczycieli języków obcych. Warto wspomnieć o jej korzeniach termin glottodidactica został w Polsce użyty po raz pierwszy w roku 1956 w nazwie czasopisma założonego przez Ludwika Zabrockiego na Uniwersytecie Poznańskim (zob. m.in. Skowronek, 2013: 10, 2014). Według Słownika PWN, glottodydaktyka to "nauka zajmująca się badaniem procesu nauczania i uczenia się języków obcych". W jej centrum stoi obecnie „szkolenie zawodowe nauczycieli języków obcych" (Grucza, Schwenk, 2010: 105), natomiast "kontur glottodydaktyki jako niezależnej nauki" w latach 70. XX wieku ukazują m.in. Bausch, Christ, Krumm (1995: 20). W dniu dzisiejszym glottodydaktyka jest uznana za dyscyplinę naukową należącą do językoznawstwa.

Poniższy przegląd podsumowuje wybrane nauki referencyjne dla glottodydaktyki jako dyscypliny naukowej. Zostały tu przedstawione te dziedziny, „których odkrycia oddziałują na (...) [tą] dyscyplinę" (Ehlich, 2010a: 28). Należą do nich na przykład:

- lingwistyka (zwłaszcza lingwistyka ogólna i stosowana, porównawcza oraz typologiczna, psycholingwistyka, socjolingwistyka, socjologia lingwistyczna), przy czym tylko „w tradycyjnym ujęciu jej przedmiotem są przede wszystkim gramatyka i leksyka danego języka" (Ehlich, 2010b: 200);

- dydaktyka, za której założyciela uznaje się Jana Amosa Komensky'ego (1562-1670), często uważana za subdyscyplinę pedagogiki; jej nazwa pochodzi od greckiego: didáskein =nauczanie, formowanie, nauka ta była i jest zatem rozumiana jako nauka o procesach nauczania i uczenia się, oraz „jako teoria treści lub kategorii edukacyjnych, jako teoria kontrolowania procesów uczenia się lub jako nauka o edukacji szkolnej (...)" (Haß, 2013: 26); w ramach samej dydaktyki ogólnej na szczególne zaakcentowanie zasługują obecnie neurodydaktyka, a także dydaktyka mediów, których wyniki badań uwzględnia się obecnie również 
Interdyscyplinarna specyfika kształcenia nauczycieli języków obcych...

w ramach dydaktyki szkoły wyższej (zob. M ayrberger, 2019: 21-23); istotny jest też dynamizm współczesnej dydaktyki próbującej sprostać wyzwaniom współczesności (zob. np. Arn, 2017);

- nauki edukacyjne/ pedagogika, której „zadaniem (...) jest naukowa analiza realiów pedagogicznych i radzenie sobie z problemami edukacji, socjalizacji i rozwoju" (Haß, 2013: 25); jej nazwa pochodzi z języka greckiego od słów paideia = edukacja lub pais = chłopiec, dziecko lub paidagogos = prowadzący dziecko; Pfeiffer (2004: $71 \mathrm{inn}$.) proponuje wyodrębnienie glottopedagogiki;

- nauki kognitywne - czyli „interdyscyplinarne podejście do badania sztucznej i naturalnej percepcji, poznania, myślenia, wiedzy i działania, ich przejawów, ich struktur i procesów (...). Znaczący wpływ na powstawanie (...) [tych dyscyplin nauki] mają prace z dziedziny psychologii, filozofii, informatyki, językoznawstwa, jak również neurologii" (Biechele, 2010: 154);

- nauka o komunikowaniu się - „rozumiana w naukach społecznych i humanistycznych z jednej strony jako nauka zajmująca się systematycznymi badaniami komunikacji [bezpośredniej] między 'nadawcą' a 'odbiorcą' (...), z drugiej zaś strony badaniami 'komunikacji pośredniej' (...), a więc za pomocą mediów" (Rost-Roth, 2010: 157).

- kulturoznawstwo - jako interdyscyplinarna nauka, „zintegrowana z takimi dyscyplinami, jak historia, polityka, sztuka, a nawet antropologia, zajmującymi się różnymi zjawiskami dotyczącymi poszczególnych kul$\operatorname{tur}(. .$.$) )" (Haß, 2013: 24);$

- studia literackie (szczególnie literatura porównawcza i ogólna teoria literacka) - czyli „studia tekstów literackich różnych gatunków (np. powieści, poezji, dramatu) jako formy ludzkiej komunikacji, eksploracji związków między autorem, tekstem i czytelnikiem, a także badanie kwestii kontekstu historycznego i roli zastosowanego kodu" (Haß, 2013: 23);

- psychologia (zwłaszcza psychologia rozwojowa, psychologia uczenia się, psychologia humanistyczna, psychobiologia/ biopsychologia) - „obszar ten ma oczywiście szczególne znaczenie dla dydaktyki języków obcych, ponieważ nauczyciele muszą być świadomi różnych form uczenia się, stylów uczenia się, a także strategii uczenia się osób uczących się (...)"; uwzględnia się tu ponadto „kwestię motywacji ucznia lub związek między wiekiem, płcią, wcześniejszą wiedzą i tożsamością ucznia" (Haß, 2013: 24), a także np. temperament (tłumaczenia własne).

Inne dyscypliny referencyjne glottodydaktyki, takie jak np. etnologia, historia, geografia kulturowa, neurolingwistyka, nauki polityczne, teoria nowych 
mediów, psycholingwistyka, socjologia także dostarczają glottodydaktyce danych empirycznych.

\section{Integracja pedeutologii i glottodydaktyki}

Osoba nauczyciela języków obcych stanowi podmiot badań wielu polskich glottodydaktyków (np. Andrzejewska, 2015; Cichoń i in., 2014; Marciniak, 2014; Pawlak i in., 2009; Wysocka, 2003). Z punktu widzenia przedstawionego dalej studium przypadku szczególne znaczenie ma wizja kształcenia nauczycieli języków obcych, łączącego aspekty pedeutologiczne i glottodydaktyczne, prezentowana przez Zawadzką-Bartnik (np. 2010, 2014). Glottodydaktyka i pedeutologia wykazują się cechami interdyscyplinarnymi, uwzględniając wyniki badań empirycznych wielu dziedzin nauki. W tym przypadku nie można mówić o dwu- lub wielodyscyplinarności, ale o interdyscyplinarności, która jest rozumiana jako „autentyczny dialog specjalistów w (...) [kilku] dziedzinach naukowych" (Wilczyńska, M ichońska-Stadnik, 2010: 26nn.). Integracja pedeutologii i glottodydaktyki wydaje się mieć w procesie kształcenia nauczycieli języków obcych wyjątkowe znaczenie. W poniższym zestawieniu dokonano uproszczonego porównania obydwu dyscyplin w tym zakresie (zob. tab. 1).

\begin{tabular}{|c|c|c|c|c|c|c|}
\hline & \multicolumn{3}{|c|}{ Glottodydaktyka } & \multicolumn{3}{|l|}{ Pedeutologia } \\
\hline Etymologia & \multicolumn{3}{|c|}{$\begin{array}{l}\text { od greckich słów glotta - język i didaskein - } \\
\text { uczyć się, nauczać }\end{array}$} & \multicolumn{3}{|c|}{$\begin{array}{l}\text { od greckich słów paideutes - nauczyciel } \\
\text { i logos - słowo, nauka }\end{array}$} \\
\hline $\begin{array}{l}\text { Podstawy } \\
\text { naukowe }\end{array}$ & \multicolumn{3}{|c|}{$\begin{array}{l}\text { Subdyscyplina w dziedzinie językoznaw- } \\
\text { stwa stosowanego }\end{array}$} & \multicolumn{3}{|c|}{ subdyscyplina w dziedzinie pedagogiki } \\
\hline $\begin{array}{l}\text { Interdyscyplinar- } \\
\text { ność (korelacja } \\
\text { wyników badań } \\
\text { z innych dyscy- } \\
\text { plin naukowych) }\end{array}$ & \multicolumn{3}{|c|}{$\begin{array}{l}\text { językoznawstwo, psycholingwistyka; socjo- } \\
\text { lingwistyka, dydaktyka ogólna, psycholo- } \\
\text { gia, pedagogika (w tym pedeutologia i glot- } \\
\text { topedagogika), nauki o komunikacji, nauki } \\
\text { kognitywne, kulturoznawstwo, literaturo- } \\
\text { znawstwo }\end{array}$} & \multicolumn{3}{|c|}{$\begin{array}{l}\text { pedagogika, psychologia, dydaktyka szkoły } \\
\text { wyższej, dydaktyka ogólna, dydaktyka po- } \\
\text { szczególnych przedmiotów szkolnych (w } \\
\text { tym dydaktyka nauczania języków obcych - } \\
\text { glottodydaktyka), nauki o komunikacji, na- } \\
\text { uki kognitywne }\end{array}$} \\
\hline jeneza nauki & \multicolumn{3}{|c|}{$\begin{array}{l}1965 \text { - Uniwersytet Poznański; termin } \\
\text { "Glottodidactica" Ludwika Zabrockiego; } \\
\text { wyodrębnianie się glottodydaktyki jako } \\
\text { niezależnej nauki od lat 70-tych XX wieku }\end{array}$} & \multicolumn{3}{|c|}{ lata 30-te XX wieku } \\
\hline Zakres badawczy & \multicolumn{3}{|c|}{$\begin{array}{l}\text { uczeń, nauczyciel, proces nauczania/ ucze- } \\
\text { nia się/ akwizycji języków obcych i jego } \\
\text { aspekty; szkolenie zawodowe nauczycieli } \\
\text { języków obcych }\end{array}$} & \multicolumn{3}{|c|}{$\begin{array}{l}\text { osobowość nauczyciela, wybór zawodu na- } \\
\text { uczyciela, przygotowanie do zawodu nau- } \\
\text { czyciela, szkolenie nauczycieli, dalsze } \\
\text { kształcenie oraz doskonalenie nauczycieli; } \\
\text { praca pedagogiczna nauczyciela (w tym ję- } \\
\text { zyków obcych) }\end{array}$} \\
\hline $\begin{array}{l}\text { Etapy rozwoju } \\
\text { dyscypliny }\end{array}$ & $\begin{array}{l}\text { metoda gra- } \\
\text { matyczno- } \\
\text { tłumacze- } \\
\text { niowa: kon- } \\
\text { centracja na } \\
\text { aspektach }\end{array}$ & \begin{tabular}{|l|} 
metoda au- \\
dio- lingualna \\
/ audiowizu- \\
alna: ele- \\
menty szko- \\
lenia języków \\
\end{tabular} & \begin{tabular}{|l|} 
podejście ko- \\
munikacyjne \\
i międzykul- \\
turowe: na \\
pierwszym
\end{tabular} & \begin{tabular}{|l|} 
podejście hu- \\
manistyczne: \\
koncentracja \\
na humani- \\
styczno-oso-
\end{tabular} & $\begin{array}{l}\text { podejście } \\
\text { technolo- } \\
\text { giczne: kon- } \\
\text { trola nau- } \\
\text { kowo-tech- } \\
\text { nologiczna }\end{array}$ & $\begin{array}{l}\text { podejście } \\
\text { funkcjonalne: } \\
\text { krytyczna re- } \\
\text { fleksja na te- } \\
\text { mat eduka- } \\
\text { cyjnego }\end{array}$ \\
\hline
\end{tabular}


Interdyscyplinarna specyfika kształcenia nauczycieli języków obcych...

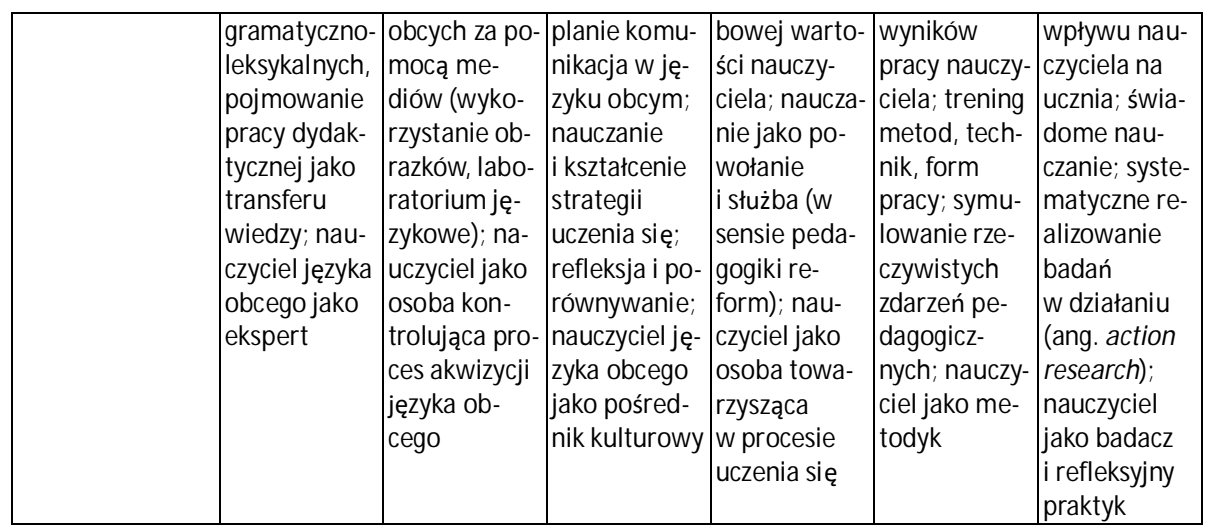

Tab. 1: Nowe tendencje w kształceniu nauczycieli języków obcych - glottodydaktyka versus pedeutologia (opracowanie własne).

W tym momencie można już jednoznacznie stwierdzić, że glottodydaktyka jako nauka wskazuje i dokonuje wyboru zagadnień do realizacji w kontekście szkolenia nauczycieli języków obcych, pedeutologia zaś jako dyscyplina naukowa wskazuje sposób, w jaki należy przekazywać te treści, tj. jakie podejścia naukowe, metody i formy pracy w zakresie dydaktyki szkoły wyższej powinny być stosowane, aby w ramach procesu kształcenia przyszli nauczyciele języków obcych zostali optymalnie przygotowani do rozwiązywania problemów edukacyjnych.

Jak już wspomniano, w niniejszym artykule istotne są te wyniki empiryczne $z$ dziedziny pedeutologii, które związane są zobszarem naukowym glottodydaktyki oraz te rezultaty badawcze z dziedziny glottodydaktyki, które dotyczą domeny pedeutologii (dla celów dalej przedstawionych badań nazywane one będą glottopedeutologicznymi). W obydwu dyscyplinach widoczny jest ich bezpośredni związek z podobnymi subdyscyplinami, w tym szczególnie z psychologią, pedagogiką, dydaktyką ogólną i prawem oświatowym, a także z dydaktyką szkoły wyższej (która zgodnie z najnowszymi tendencjami ma być zorientowana na rozwój kompetencji studentów, a nie tylko na przekazywanie teorii naukowych) (zob. M acke, Hanke, Viehmann-Schweizer, Raether 2016). Nowocześnie zorganizowany, a więc nastawiony na interdyscyplinarność, proces kształcenia nauczycieli języków obcych, nie powinien polegać jedynie na imitowaniu czy rozwijaniu krytycznego myślenia, lecz zachęcać studentów do myślenia komputacyjnego, czyli do świadomego poszukiwania nowych rozwiązań i samodzielnego wyciągania wniosków w wyniku refleksji nad wszelkimi podejmowanymi działaniami (zob. tab. 2). 


\begin{tabular}{|c|c|c|c|}
\hline $\begin{array}{l}\text { Organizacja nowocze } \\
\text { Od nabywania wiedzy } \\
\text { Od reprodukowania < }\end{array}$ & snego glottopedeutologic & $\begin{array}{l}\text { nego kształcenia naucz } \\
\text { rozwijania, pogłębiani } \\
\text { vanie <----->> do f }\end{array}$ & $\begin{array}{l}\text { ycieli języków obcych } \\
\text { a i poszerzania wiedzy } \\
\text { formułowania hipotez }\end{array}$ \\
\hline Typ & M yślenie imitacyjne & M yślenie krytyczne & $\begin{array}{l}\text { Myślenie } \\
\text { komputacyjne }\end{array}$ \\
\hline $\begin{array}{l}\text { Aktywność/działania } \\
\text { studentów: }\end{array}$ & $\begin{array}{l}\text { - streszczanie } \\
\text { - opisywanie } \\
\text { - rozpoznawanie i stoso- } \\
\text { wanie } \\
\text { - opanowanie wiedzy, za- } \\
\text { sad, reguł } \\
\text { - zdobywanie, poszerza- } \\
\text { nie i pogłębianie wie- } \\
\text { dzy }\end{array}$ & $\begin{array}{l}\text { - analizowanie facho- } \\
\text { wej literatury } \\
\text { - ocenianie pomysłów } \\
\text { i informacji } \\
\text { - synteza wiedzy, wy- } \\
\text { ciąganie wniosków, } \\
\text { formułowanie argu- } \\
\text { mentów }\end{array}$ & $\begin{array}{l}\text { - zdobywanie się na } \\
\text { własną refleksję } \\
\text { - ocenianie z wła- } \\
\text { snego punktu wi- } \\
\text { dzenia } \\
\text { - spekulowanie } \\
\text { - formułowanie hi- } \\
\text { potez }\end{array}$ \\
\hline $\begin{array}{l}\text { Charakterystyczne } \\
\text { pytania naukowe: }\end{array}$ & $\mathrm{CO} ?$ & $\begin{array}{c}\text { jak? w jaki sposób? } \\
\text { jak dalece istotne? } \\
\text { dlaczego? }\end{array}$ & co by było, gdyby? \\
\hline Cele & poprawność & $\begin{array}{l}\text { prosta oryginalność } \\
\text { transfer wiedzy } \\
\text { i umiejętności }\end{array}$ & twórcza oryginalność \\
\hline
\end{tabular}

Tab. 2: Nowe trendy w glottodydaktyce i pedeutologii - organizacja nowoczesnego procesu glottopedeutologicznego (opracowanie własne na podstawie Ballard, Clancy, 1991).

Student w nowoczesnym procesie glottopedeutologicznego kształcenia przygotowującego do wykonywania zawodu nauczyciela języka obcego nie tylko powinien zapamiętywać i zdobywać szeroką wiedzę z zakresu psychologii, pedagogiki, dydaktyki ogólnej, glottodydaktyki czy prawa oświatowego, powinien też poprzez krytyczne myślenie, zakotwiczone w analizie i syntezie literatury fachowej z różnych dyscyplin pokrewnych oraz transfer poznanych rozwiązań dydaktycznych na praktykę pedagogiczną rozwijać postawę myślenia komputacyjnego, mającego na celu twórcze i świadome poszukiwanie nowych, oryginalnych rozwiązań opiekuńczo-wychowawczych oraz glottodydaktycznych.

\section{Interdyscyplinarna specyfika kształcenia nauczycieli języków obcych - metodologia badań własnych}

\subsection{Cel badań, podejście empiryczne, metody i techniki badawcze}

Celem badań jest analiza interdyscyplinarnej specyfiki kształcenia nauczycieli języków obcych, realizowanego w ramach studiów uniwersyteckich pierwszego i drugiego stopnia. Z metodologicznego punktu widzenia mają one charakter jakościo wy z elementami ilościowymi i uwzględniają zasadę triangulacji (zob. Knorr, Schramm, 2016: 90 i nn.; Röbken, Wetzel 2016: 13; Schramm, 
2016: 50 i nn.; Frieberthäuser, Langer, Prengel, 2013, 17-18). Zastosowano w nich metodę biograficzną, analizę dokumentów, ankietowanie, obserwację i metodę dialogową, a także elementy badań korpusowych oraz badań w działaniu. M etoda biograficzna obejmuje tutaj studium przypadku (Łobocki, 2000: 243 i nn.) kształcenia nauczycieli języka niemieckiego realizowanego w Instytucie Germanistyki Uniwersytetu Warszawskiego i skierowana jest na pozyskiwanie danych empirycznych dotyczących studentów i glottopedeutologów biorących udział w procesie kształcenia oraz danych obejmujących formy, metody, warunki kształcenia itp. Analiza dokumentów obejmuje wnioskowanie klasyczne, jakościowe i formalne na podstawie dokumentów oficjalnych, półoficjalnych oraz prywatnych, a konkretnie analizę przepisów prawnych, programów kształcenia nauczycieli języka obcego, sylabusów akademickich, dokumentów praktyk pedagogicznych oraz pisemnych i ustnych wypowiedzi studentów oraz wykładowców na temat praktyk i procesu kształcenia. M etoda sondażu (Łobocki, 2000: 243 i nn.) realizowana jest w niniejszych badaniach poprzez techniki pisemnego sondażu z zastosowaniem ankiety skategoryzowanej, zawierającej zarówno pytania zamknięte, półotwarte, jak i otwarte, oraz techniki ustnego sondażu z zastosowaniem wywiadu niestandaryzowanego. Obserwacja natomiast realizowana jest w niniejszych badaniach przede wszystkim jako autoobserwacja. Na podstawie autorefleksji badani glottopedeutolodzy formułują w sposób pisemny indywidualne opinie na temat procesu kształcenia. W ramach metody dialogowej przeprowadzono i przeprowadza się nadal wywiady z wybranymi studentami na temat kształcenia nauczycieli, a więc indywidualne, bezpośrednie rozmowy uwzględniające aktywne słuchanie (polegające na upewnianiu się badacza co do poprawności rozumienia wypowiedzi w trakcie jej trwania) i listy ogólnych, głównych kategorii (czyli zagadnień, których dotyczyć ma rozmowa).

\subsection{Kryteria poprawności badań, proces empiryczny i pytania badawcze}

Zastosowana procedura badawcza ma pomóc zapewnić nie tylko wiarygodność, obiektywność, trafność i rzetelność wyników, ale także spełnienie kryteriów poprawności jakościowych badań empirycznych, takich jak otwartość, elastyczność oraz komunikatywność (zob. Łobocki, 2000; Wilczyńska, M ichońska-Stadnik, 2010; Caspari i in., 2016).

Badania realizowane są od roku 2011 w Instytucie Germanistyki Uniwersytetu Warszawskiego i trwają nadal (zob. Karpeta-Peć, 2018: 25-42). Poniżej przedstawiono tylko niektóre dane empiryczne dotyczące interdyscyplinarnej specyfiki kształcenia nauczycieli języków obcych. Pytanie badawcze dla celów niniejszego artykułu można sformułować następująco: Na czym polega 
interdyscyplinarna specyfika kształcenia nauczycieli języków obcych? Pytanie to implikuje kilka pytań szczegółowych:

- Jaką rolę w procesie kształcenia nauczycieli języków obcych pełni pedeutologia? Czy rzeczywiście stanowi jego mocny filar i określa sposób realizacji ścieżki kształcenia nauczycieli języków obcych?

- Jaką rolę w procesie kształcenia nauczycieli języków obcych pełni glottodydaktyka? Czy rzeczywiście również stanowi jego mocny filar i określa zakres zagadnień realizowanych w procesie kształcenia?

- Jakie dziedziny i dyscypliny naukowe stanowią podstawę dla wiedzy przekazywanej studentom w procesie kształcenia nauczycielskiego?

- W jaki sposób przekazywana jest wiedza, trenowane są umiejętności i kształtowane postawy przyszłych nauczycieli języków obcych? Według pedeutologicznej orientacji technologicznej, humanistycznej czy funkcjonalnej?

Przytoczone zostaną wybrane wyniki pozyskane w ramach studium przypadku, rozumianego jako przypadek badania specyfiki interdyscyplinarnego kształcenia nauczycieli języków obcych w jednym z polskich instytutów neofilologicznych, na podstawie analizy dokumentów prawnych i merytorycznych oraz sondażu przeprowadzonego wśród studentów (dla celów niniejszego artykułu wybrano dane sondażu ustnego, pozyskane od jednego studenta).

\section{Interdyscyplinarna specyfika kszałcenia nauczycieli języków obcych - wyniki badań własnych}

\subsection{Wyniki analizy dokumentów}

Jeszcze do niedawna proces kształcenia nauczycieli języków obcych realizowany był na podstawie Rozporządzenia Ministra Nauki i Szkolnictwa Wyższego z 17 stycznia 2012 roku w sprawie standardów kształcenia przygotowującego do wykonywania zawodu nauczyciela (Dz. U. 2012 poz. 131). W ostatnim czasie weszło w życie Rozporządzenie M inistra Nauki i Szkolnictwa Wyższego z dnia 25 lipca 2019 r. w sprawie standardu kształcenia przygotowującego do wykonywania zawodu nauczyciela (Dz. U. 2019 poz. 1450). Od 2012 r. kształcenie nauczycieli języków obcych na uczelniach wyższych obejmuje przygotowanie merytoryczne wynikające z programu danego kierunku studiów (moduł 1 według Rozporządzenia z 2012 r. oraz grupa zajęć A według Rozporządzenia z 2019 r.), przygotowanie psychologiczno-pedagogiczne (moduł 2 według Rozporządzenia z 2012 r. oraz grupa zajęć B według Rozporządzenia z 2019 r.), przygotowanie dydaktyczne (moduł 3 według Rozporządzenia z 2012 r. oraz grupa zajęć C, czyli podstawy dydaktyki 
Interdyscyplinarna specyfika kształcenia nauczycieli języków obcych...

i emisja głosu, a także grupa zajęć $D$, czyli przygotowanie dydaktyczne do nauczania danego języka obcego według Rozporządzenia z 2019 r.).

Już wstępny przegląd tych dokumentów prawnych ukazuje interdyscyplinarną specyfikę kształcenia nauczycieli języków obcych. W ramach studiów merytorycznych (moduł 1 według Rozporządzenia z 2012 r. oraz grupa zajęć A według Rozporządzenia z 2019 r.) na odpowiednich neofilologicznych kierunkach studiów pierwszego stopnia uwzględnia się na przykład takie dziedziny nauki, jak: lingwistyka, literaturoznawstwo, teoria literatury, realioznawstwo, filozofia, historia, kulturoznawstwo, psychopedagogika, dydaktyka i glottodydaktyka (por. Program studiów I stopnia na kierunku germanistyka obowiązujący od 2018 r. w Instytucie Germanistyki Uniwersytetu Warszawskiego). Z kolei studia magisterskie poświęcone są zdobywaniu pogłębionej wiedzy z zakresu takich dyscyplin naukowych, jak: historia kultury, komparatystyka kulturowa, studia nad komunikacją międzykulturową, glottodydaktyka, językoznawstwo z elementami tłumaczeń, historia literatury, krytyka literacka, translatoryka literacka, studia transkulturowe, a także aktualnie helwetologia i komunikacja w biznesie (por. Program studiów stacjonarnych II stopnia na kierunku germanistyka obowiązujący od 2018 r. w Instytucie Germanistyki Uniwersytetu Warszawskiego). Takie przygotowanie merytoryczne studentów - w tym przyszłych nauczycieli języka obcego - dobrze rokuje. Słuchacze mają możliwość zdobywania merytorycznej wiedzy z zakresu różnorodnych dziedzin i dyscyplin naukowych.

Podobnie interdyscyplinarnie wygląda przygotowanie psychologicznopedagogiczne według obydwu omawianych rozporządzeń. Różnica widoczna jest jedynie w sposobie usystematyzowania wiedzy i umiejętności. W Rozporządzeniu z 2012 r. obszary psychologiczny i pedagogiczny były zintegrowane i obejmowały, po pierwsze - ogólne przygotowanie psychologiczno-pedagogiczne (moduł 2.1./ 90 godz.), po drugie zaś - przygotowanie psychologicznopedagogiczne do nauczania na danym etapie edukacyjnym lub etapach edukacyjnych (moduł 2.2./ 60 godz.) oraz praktykę psychologiczno-pedagogiczną (moduł 2.3./ 30 godz.). Obecnie według Rozporządzenia z 2019 r. wyodrębnia się psychologię (90 godz.), pedagogikę $(90 \mathrm{godz}$ ) ) oraz praktyki zawodowe (30 godz.). Liczba godzin poświęcona zagadnieniom z dziedzin psychologii i pedagogiki została zatem zwiększona o 30.

Pogłębiona analiza sylabusów poszczególnych przedmiotów z modułu psychologiczno-pedagogicznego ukazuje powiązanie omawianych zagadnień z wynikami badań empirycznych takich dziedzin i dyscyplin, jak: glottodydaktyka, psychologia, pedagogika, a także socjologia, nauki kognitywne, nauki prawne, nauki o komunikacji społecznej, prawo, medycyna, biologia, antropologia. Istotne jest czerpanie w ramach samej psychologii z wielu subdyscyplin, 
takich jak psychologia ogólna, psychologia rozwojowa, psychologia pedagogiczna, psychologia różnic indywidualnych, psychologia osobowości, psychobiologia (zob. np. Horstmann, Dreisbach, 2017; Spering, Schmidt, 2017; Woolfolk, 2014; Schneider, Lindenberger, 2012; Salewski, Renner, 2009). W bloku pedagogicznym sięga się do teorii wychowania, pedagogiki ogólnej, pedagogiki specjalnej (w tym np. oligofrenopedagogiki), aksjologii pedagogicznej, pedagogiki reform (zob. np. Chałas, Maj, 2016; Heimlich, 2016; Kwieciński, śliwerski 2003). Wszystkie wyżej wymienione dziedziny i dyscypliny naukowe stanowią następnie teoretyczną bazę dla realizacji praktyk (w omawianym przykładzie - Praktyki psychologiczno-pedagogicznej). ${ }^{1}$

W interdyscyplinarnym kształceniu dydaktycznym (moduł 3) wyraźnie podkreślano różnicę między wiedzą i umiejętnościami ogólnodydaktycznymi (moduł 3.1.), glottodydaktycznymi (moduł 3.2.) oraz praktycznymi (moduł 3.3.). Obecnie wyodrębnia się dydaktykę ogólną z emisją głosu (grupa zajęć C) oraz dydaktykę przedmiotu - w omawianym przypadku glottodydaktykę (grupa zajęć D). Zanalizy sylabusów poszczególnych przedmiotów modułu dydaktycznego wynika, że słuchacze podczas studiów zdobywają wiedzę z dziedzin i dyscyplin takich jak dydaktyka ogólna (np. Lehner, 2009) (w tym dydaktyka medialna) i glottodydaktyka (Jaroszewska, 2014), a także z zakresu językoznawstwa, psychologii (w tym psychologii rozwojowej), pedagogiki, w tym pedagogiki specjalnej (np. Zawadzka-Bartnik, 2010) i medialnej, nauk prawnych (prawa oświatowego), nauk o komunikacji społecznej i mediach, jak również, w ramach studiów II stopnia, bezpośrednio z pedeutologii. Wszystkie wymienione dziedziny i dyscypliny naukowe stanowią, podobnie jak w module 2 , podstawę do realizacji praktyki - w omawianym przypadku Wstępnej praktyki dydaktycznej o charakterze obserwacyjnym oraz Zasadniczej praktyki dydaktycznej polegającej na samodzielnym prowadzeniu lekcji języka obcego (tu: języka niemieckiego). ${ }^{2}$

Zakłada się, iż do podobnych wniosków można dojść analizując sylabusy przedmiotów w ramach kształcenia nauczycieli języków obcych na innych uczelniach w Polsce, programy kształcenia bazują bowiem na jednolitych standardach prawnych.

W nowym rozporządzeniu wymienia się ponadto w ramach treści kształcenia nauczycieli filozofię wychowania i nawiązuje się w większym stopniu do

\footnotetext{
${ }^{1}$ W aneksie zamieszczono przykładowe zestawienie treści realizowanych w ramach ogólnego przygotowania psychologiczno-pedagogicznego (tab. 3) oraz przygotowania psychologiczno-pedagogicznego do nauczania na danych etapach edukacyjnych (tab. 4).

${ }^{2}$ Aneks zawiera przykładowe zestawienie treści realizowanych w ramach przygotowania dydaktycznego (tab. 5). Tamże zamieszczono również wykaz przedmiotów oferowanych w badanym czasie w Instytucie Germanistyki UW (tab. 6).
} 
psychologii rehabilitacji i pedagogiki specjalnej (np. eksponując edukację włączającą) oraz do logopedii (akcentując na przykład zagadnienia z dziedziny emisji głosu). Znaczenia nabierają też nauki o komunikacji medialnej (np. w ramach zagadnień cyfryzacji czy myślenia komputacyjnego). Ze względu na złożoność procesu kształcenia nauczycieli języków obcych i wyjątkowej roli, jaką odgrywają w nim obydwie wyżej wspomniane dyscypliny: glottodydaktyka i pedeutologia, w badanym przypadku realizuje się zajęcia uniwersyteckie według autorskiego podejścia glottopedeutologicznego.

\subsection{Wyniki sondażu ustnego}

W ramach omawianych tutaj badań przeprowadzone były (i są nadal) wywiady z wybranymi studentami. We wszystkich dotychczasowych wypowiedziach widoczne są elementy trzech orientacji pedeutologicznych: technologicznej, humanistycznej i funkcjonalnej oraz wpływ wiedzy z wielu dyscyplin naukowych. W niniejszym artykule przytoczone zostaną przykładowe opinie jednego studenta (S3), które dokładnie ukazują specyfikę kształcenia nauczycieli języków obcych. Osoba ta w momencie badania miała już za sobą proces kształcenia nauczycielskiego w ramach studiów pierwszego stopnia oraz zajęcia akademickie przypisane dla pierwszego roku studiów drugiego stopnia, a więc zdobyła interdyscyplinarną wiedzę ze wszystkich przedstaw ionych wyżej dyscyplin naukowych. Student zrealizował trzy etapy praktyk w szkołach podstaw owych i przedszkolach: Praktykę psychologiczno-pedagogicznq - I i II etap edukacyjny (30 godz. obserwacji lekcji wychowawczych i innych działań opiekuńczo-wychowawczych), Wstępnq praktykę dydaktycznq - I i II etap edukacyjny (60 godz. obserwacji lekcji języka niemieckiego, częściowo też innych przedmiotów) oraz Zasadniczq praktykę dydaktycznq - I i II etap edukacyjny (60 samodzielnie prowadzonych lekcji języka niemieckiego).

Wywiad miał charakter nieustrukturyzowany i uczestniczący, co oznacza, że nie przygotowano wcześniej pytań badawczych, a badacz reagował swymi pytaniami na sytuacje zaistniałe podczas rozmowy. Z wypowiedzi studenta widać, że cały proces kształcenia (stacjonarnego) postrzega on przede wszystkim jako okazję do zdobywania pogłębionej wiedzy, natomiast dopiero praktyki pedagogiczne widzi jako możliwość rzeczywistego treningu umiejętności: Więc to było tak, że najpierw miałem porcję teorii, którq później mogłem zobaczyć - [przeżyć,] jak to wszystko działa - w praktyce. ${ }^{3}$ Nie bez znaczenia są jednak też wszystkie sytuacje podczas zajęć uniwersyteckich, kiedy to studenci w sposób nie do końca naturalny mają możliwość ćwiczyć sposoby prowadzenia

${ }^{3}$ Przytoczono oryginalne wypowiedzi badanego. 
zajęć. Są to przede wszystkim prezentacje oraz micro-teaching (krótkie, pięciominutowe symulacje lekcji): No, na pewno wszystkie prezentacje, które przygotowywałem, nauczyły mnie też tego, jak się przygotowywać do jakiegoś wystqpienia, ale też - myślę - trochę mnie (...) ośmieliły przed (...) pójściem do szkoły. Bo to też było potrzebne - nie tak, żeby siedzieć w tawce i słuchać innych, ale też nauczyć się występować. No i też na pewno takiego przygotowania samodzielnego - to zdecydowanie. W obrębie studentów ćwiczyłem - czyli micro-teaching. Ale właściwie, jak to jest naprawdę, to się przekonałem podczas sześćdziesięciu godzin praktyk. Wiec tutaj miałem taki wstęp, a zobaczyć mogłem, jak to wszystko wyglqda już w praktyce. (...) Byłem przygotowany [do konfrontacji z rzeczywistością] w takim znaczeniu, że wiedziałem, co mnie może czekać. Nie ćwiczyliśmy tutaj z dziećmi, bo nie zapraszaliśmy nigdy dzieci, ale trenowaliśmy takie sytuacje, które mogq spotkać nauczyciela w szkole. Więc byłem przygotowany na to, co może mnie czekać na praktykach.

Zdaniem badanego studenta, podczas całej ścieżki kształcenia miał on możliwość rozwijania swojej autonomii jako potencjalny nauczyciel języka niemieckiego, a także poznawać siebie samego, swoje mocne strony i talenty, oraz realizować swoje zainteresowania: To były tematy wyznaczone przez prowadzqcych, ale zawsze mogłem coś takiego znaleźć i rozszerzyć, co mnie interesowało. Oferta kształcenia nauczycielskiego, z której student korzysta, jest w jego subiektywnej opinii zdecydowanie ukierunkowana na działanie i aktywność.

W jego wypowiedziach widoczne są elementy orientacji humanistycznej, kiedy zwraca uwagę na indywidualne potrzeby swoich kolegów i koleżanek biorących udział w procesie nauczycielskiego kształcenia. W jego opinii całe kształcenie jest dostosowane do tego, żeby student sam się rozwinął i siebie samego urzeczywistnił, dzięki zdobywaniu i ciągłemu pogłębianiu wiedzy, także o sobie samym: Tak. Wydaje mi się, że tak. I to, że czasami przygotowujemy i że nie mamy odpowiedzi danych, gotowych, tylko musimy je znaleźć, to na pewno dzięki temu się też na pewno rozwijamy. Jest to trudniejsza droga nie powiem - bo łatwiej by było się nauczyć po prostu czegoś gotowego, ale jest to na pewno rozwijajqce i też pokazuje nam, że jesteśmy w stanie sami do czegoś dojść, sami jakieś informacje znaleźć.

O technologicznym zorientowaniu procesu kształcenia nauczycielskiego świadczą na przykład takie fragmenty wypowiedzi: To jest naprawdę taka baza, którq można kiedyś wykorzystać, no i sprawdzić, jak ta cała teoria działa w praktyce; W łaśnie to też jest takie ciekawe, że ćwiczymy na sobie nawzajem. W grupach zajęciowych stwarzamy sobie takie możliwości, że jedna osoba jest jakby nauczycielem, a pozostałe osoby uczniami, i staramy się wykreować takie sytuacje szkolne. Więc myślę, że zdecydowanie możemy się nauczyć takiej pracy. Jako przykład student podaje otwarte formy pracy, w których uczestniczył 
podczas zajęć uniwersyteckich, ale też sam miał okazję je przygotowywać: Nie próbowałem jeszcze z dziećmi takiej formy [pracy], na przykład zajęć poprzez rozwiq̨zywanie zadań na stacjach dydaktycznych. Na razie ćwiczyłem tylko ze studentami te formy, ale bardzo mi się podobało. I też to, że każdy robiłto, co chciał, każdy coś innego i różne rzeczy z tego wychodziły, i każdy tak naprawdę wyciqgną coś dla siebie z tych zajęć. Bardzo mi się to podobało. Zdobywana wiedza stanowi zatem podstawę dla praktyki - dzięki rozwijaniu umiejętności krytycznego myślenia.

Zdaniem badanego krytyczne rozważania i transfer wiedzy prowadzą z kolei do osobistych refleksji, a więc rozwijają świadome myślenie komputacyjne - poszukiwanie własnych rozwiązań dla potencjalnych problemów: Myślę, że w przyszłości, kiedy już nie będę miał takiego zaplecza, że pójdę na zajęcia i zapytam, to będzie to bardzo pomocne. Kształcenie nauczycielskie ma zatem zdecydowanie funkcjonalny charakter i stwarza możliwości krytycznego i refleksyjnego podejścia do wiedzy: To znaczy, wydaje mi się, że tak omawialiśmy z różnych punktów widzenia jakiś aspekt. To też jest ciekawe, że każdy przygotowuje na początku jakieś informacje i wtedy widzimy, że każdy ma jakiś inny punkt widzenia. ${ }^{4}$ to ... To tak nam pozwoliło spojrzeć na dany problem nie tylko z jednej strony, ale tak globalnie, z wielu stron. (...) Myślę, że zdecydowanie, bo omawiamy tu bardzo dużo aspektów i one wszystkie majq zastosowanie później w szkole. Więc zdecydowanie maja te zajęcia charakter funkcjonalny i bardzo dużo mi dały. Bo - tak jak mówię, nie wiedziałem zupełnie, jak wyglqadajq lekcje języka niemieckiego w szkole podstawowej (...). Więc dobrze, że miałem takq bazę (...) i mogłem jq zastosować w praktyce.

\subsection{Wnioski i perspektywy badawcze}

Dotychczasowe rozważania teoretyczne i przytoczone wyniki badań własnych skłaniają do następujących wniosków:

1. Proces kształcenia nauczycieli języków obcych ma interdyscyplinarną specyfikę.

2. Proces ten bazuje na dwóch mocnych filarach glottodydaktyce i pedeutologii, dyscyplinach, które są ze sobą mocno sprzężone.

3. Ze względu na specyfikę tego procesu proponuje się termin glottopedeutologiczne kształcenie nauczycieli języków obcych.

4. Glottodydaktyka określa zakres zagadnień realizowanych w procesie kształcenia nawiązując do wielu dyscyplin naukowych z dziedziny

4 Chodzi o metodę stosowaną regularnie na początku zajęć, kiedy każdy student krótko przedstawia to, co przygotował na temat danego zagadnienia zgodnie z własnymi zainteresowaniami. 
nauk humanistycznych i społecznych, w sposób szczególny do psychologii, pedagogiki, dydaktyki ogólnej i prawa oświatowego.

5. Pedeutologia określa sposób realizacji ścieżki kształcenia nauczycieli języków obcych - optymalnie według zintegrowanej orientacji humanistyczno-technologiczno-funkcjonalnej.

Przytoczone w niniejszym artykule wybrane wyniki stanowią niewielki fragment pogłębionych badań empirycznych, które są w realizowane w naszej placówce. Cenne byłoby przeprowadzenie podobnych badań jakościowo-ilościowych z elementami triangulacji i uwzględnienie praktycznych badań edukacyjnych oraz badań korpusowych w innych neofilologicznych jednostkach akademickich.

\section{Podsumowanie}

Przedstawiony model kształcenia z pewnością nie jest doskonały. Nie ma doskonałych glottopedeutologów, nie ma też doskonałych kandydatów do zawo du nauczyciela języków obcych. M ożliwe jest natomiast zastosowanie efektywnego rozwiązania: to na relacji trenera ze studentem bazuje dobry proces kształcenia. Podczas studiów chodzi nie tylko o indywidualne podejście do każdego potencjalnego nauczyciela, ale o personalizację, a więc dostosowanie kształcenia do osobistych potrzeb danego studenta. To, co proponuje się przyszłemu nauczycielowi, ten konfrontuje z dotychczasowymi doświadczeniami (z edukacji, ze studiów, z domu rodzinnego). Trzeba niezwykłej pokory, by dostrzec, jak bardzo złożony jest podmiot glottopedeutologii.

Reasumując, konieczne jest implikowanie wielu obszarów wiedzy w taki sposób, by dopomóc danej osobie w osiągnięciu celów na miarę jej możliw ości. Glottopedeutolog zatem nie tyle przekazuje wiedzę (skłaniając studentów do myślenia imitacyjnego) oraz metody i techniki pracy z przyszłymi uczniami (zachęcając do krytycznego myślenia), ile raczej inspiruje osobę studenta do samodzielnego poszukiwania: zdobywania i pogłębiania wiedzy, nabywania nowych umiejętności, odkrywania form i sposobów pracy, które dla niego będą odpowiednie i optymalne (a więc myślenia komputacyjnego). Wykładowca, który jest jednocześnie trenerem i opiekunem praktyk nie tylko powinien dostrzegać złożoność osobowości każdego ze swoich podopiecznych, lecz przede w szystkim musi starać się dostosować sposoby kształcenia tak, by możliwe było osiągnięcie przez nich samorealizacji. Humanistyczna orientacja procesu kształcenia nauczycieli języków obcych będzie zatem kompetentnym towarzyszeniem w rozwoju przyszłego anglisty, germanisty, romanisty itp. Od strony technologicznej student powinien mieć możliw ość aktyw nego treningu nauczycielskich umiejętności, na przykład poprzez symulacje lekcji z wykorzystaniem 
różnorodnych, inspirujących, aktywizujących, otwartych form, metod i technik pracy m.in. w ramach zajęć o charakterze psychologiczno-pedagogiczno(glotto-)dydaktycznych warsztatów. Proces kształcenia nauczycieli języków obcych nie przyniesie jednak w pełni zamierzonych efektów, jeśli nie będzie wpisane weń kształcenie postawy refleksyjnej. To glottopedeutolog jako trener w procesie funkcjonalnego kształcenia nauczycieli zachęca studentów do autorefleksji i wyciągania pogłębionych wniosków co do potencjalnej pracy. Dopiero zatem połączenie wszystkich trzech orientacji w spersonalizowanym podejściu przyniesie optymalne rezultaty. Korzystanie przez danego studenta z różnych dziedzin nauki jest niejako naturalne i realizowane zarówno w ramach przygotowania psychologicznego, pedagogicznego i (glotto)dydaktycznego, jak też merytorycznego w ramach danego kierunku studiów, prowadzącego do zdobycia uprawnień do nauczania języka obcego.

\section{BIBLIOGRAFIA}

Andrzejewska E. (red.) (2015), Kształcenie nauczycieli języków obcych. „Neofilolog", $\mathrm{nr} 44 / 2$.

Arends R. I. (1994), Uczymy się nauczać. Warszawa: Wydawnictwa Szkolne i Pedagogiczne.

Arn Ch. (2017), Agile Hochschuldidaktik. Weinheim, Basel: Beltz Juventa Verlag. Ballard B., Clancy J. (1991): Assessment by M isconception: Cultural Influences and Intellectual traditions, (w:) Hamp-Lyons L. (red.), Assessing Second Language Writing in Academic Contexts. Westport: Ablex Publishing.

Bausch K.-R., Christ H., H.-J. Krumm (1995), Das Lehren und Lernen von fremden Sprachen: Wissenschaftskonzepte im internationalen Vergleich, (w:) Bausch K.-R. i in. (red.), Handbuch Fremdsprachenunterricht. Tübingen, Basel: Francke Verlag, s. 13-23.

Biechele B. (2010), Kognitionswissenschaft, (w:) Barkowski H., Krumm H.-J. (red.), Fachlexikon Deutsch als Fremd- und Zweitsprache. Tübingen, Basel: Francke Verlag, s. 154.

Caspari D., Clippel F., Legutke K., Schramm K. (red.) (2016), Forschungsmethoden in der Fremdsprachendidaktik. Tübingen: Narr Francke Attempto Verlag.

Cichoń M . i in. (red.) (2014), Przez praktyki do praktyki. W stronę innowacyjności w kształceniu nauczycieli. Część druga. Języki obce. Lublin: Uniwersytet Marii Curie- Skłodowskiej.

Chałas K., M aj A. (red.) (2016), Encyklopedia Aksjologii Pedagogicznej. Radom: Polskie Wydawnictwo Encyklopedyczne. 
Ehlich K. (2010a): Bezugswissenschaft, (w:) Barkowski H., Krumm H.-J. (red.), Fachlexikon Deutsch als Fremd- und Zweitsprache. Tübingen, Basel: Francke Verlag, s. 28-29.

Ehlich, K. (2010b), Linguistik, (w:) Barkowski H., Krumm H.-J. (red.), Fachlexikon Deutsch als Fremd- und Zweitsprache. Tübingen, Basel: Francke Verlag, s. 200-201.

Frieberthäuser B., Langer A., Prengel A. (2013), Perspektiven qualitativer Forschung in der Erziehungswissenschaft - eine Einführung, (w:) Frieberthäuser B., Langer A., Prengel A. (red.), Handbuch. Qualitative Forschungsmethoden in der Erziehungswissenschaft. Weinheim, Basel: Beltz Juventa Verlag, s. 17-39.

Grucza F., Schwenk H.-J. (2010), Glottodidaktik, (w:) Barkowski H., Krumm H.J. (red.), Fachlexikon Deutsch als Fremdsprache. Tübingen, Basel: A. Francke Verlag, s. 105.

Haß F. (2013), Die Bezugsdisziplinen der Fremdsprachendidaktik, (w:) Hallet W., Königs F. G. (red.), Handbuch Fremdsprachendidaktik. Seelze-Velber: Klett/ Kallmeyer, s. 22-27.

Heimlich U. (2016), Pädagogik bei Lernschwierigkeiten. Bad Heilbrunn: Verlag Julius Klinkhardt.

Hofer S. (2010), Lehrerausbildung, (w:) Barkowski H., Krumm H.-J. (red.), Fachlexikon Deutsch als Fremdsprache. Tübingen, Basel: A. Francke Verlag, s. 185-186.

Horstmann G., Dreisbach G. (2017), Allgemeine Psychologie 2 kompakt. Weinheim, Basel: Psychologie Verlagsunion in der Verlagsgruppe Beltz.

Jaroszewska A. (2014), 0 glottodydaktyce słowami glottodydaktyków. „Języki Obce w Szkole", nr 4, s. 52-66.

Karpeta-Peć B. (2018), Afekt vs. efekt - otwarte formy pracy z perspektywy glottodydaktycznej. „Roczniki Humanistyczne”, nr 10, s. 25-42.

Knorr P., Schramm, K. (2016), Triangulation, (w:) Caspari D., Clippel F., Legutke

K., Schramm K. (red.), Forschungsmethoden in der Fremdsprachendidaktik. Tübingen: Narr Francke Attempto Verlag, s. 90-97.

Kuźma J. (2009), Projekcja optymalnego systemu pedagogicznego kształcenia i doskonalenia nauczycieli. Weryfikacja prognozy, (w:) Szempruch J., Blachnik-Gęsiarz M. (red.), Adaptacja zawodowa nauczyciela. Częstochowa: Wydawnictwo Szkoły Lingwistycznej, s. 209-228.

Kwiatkowska H. (2008), Pedeutologia. Warszawa: Wydawnictwa Akademickie i Profesjonalne.

Kwieciński, Z., śliwerski, B. (red.) (2003), Pedagogika. Warszawa: Wydawnictwo Naukowe PWN.

Lehner M. (2009), Allgemeine Didaktik. Bern, Stuttgart, Wien: Haupt Verlag. 
Interdyscyplinarna specyfika kształcenia nauczycieli języków obcych...

Łobocki M. (2000), M etody i techniki badań pedagogicznych. Kraków: Oficyna Wydawnicza Impuls.

M acke G., Hanke U., Viehmann-Schweizer P., Raether W. (2016), Kompetenzorientierte Hochschuldidaktik. Lehren - vortragen - prüfen - beraten. Weinheim, Basel: Beltz Verlag.

Malinowska J. (2008), Kompetencje komunikacyjne nauczycieli jako wyznacznik poczucia podmiotowości uczniów w szkole. Diagnoza - biograficzny wymiar ich u/formowania. Wrocław: Oficyna wydawnicza ATUT.

Marciniak I. (2014), Rola refleksji w procesie przygotowania do zawodu nauczyciela języka obcego. „Neofilolog”, nr 43/1, s. 39-53.

Matyjas B., Ratajek, Z., Trafiałek, E. (1997), Orientacje i kierunki w pedagogice współczesnej (zarys problematyki). Kielce: Wszechnica Świętokrzyska.

Mayrberger K. (2019), Partizipative M ediendidaktik. Gestaltung der (Hochschul-)Bildung unter den Bedingungen der Digitalisierung. Weinheim, Basel: Beltz Juventa Verlag.

M izerek H. (1999), Dyskursy współczesnej edukacji nauczycielskiej. M iędzy tradycjonalizmem i ponowoczesnościq. Olsztyn: Uniwersytet Warmińsko-M azurski.

Paris S. G., Ayres L. R. (1997), Stawanie się refleksyjnym uczniem i nauczycielem. Warszawa: Wydawnictwa Szkolne i Pedagogiczne.

Pawlak M., M ystkowska-Wiertelak A., Pietrzykowska A. (red.) (2009), Nauczyciel języków obcych dziś i jutro. Poznań-Kalisz: Wydawnictwo Uniwersytetu Adama Mickiewicza.

Pfeiffer W. (2004), Interkulturowa glottopedagogika - nowa dyscyplina naukowa? Uwagi do dyskusji, (w:) Badstübner-Kizik C., Rozalowska-Żądło R., Uniszewska A. (red.): Sprachen Lehren. Sprachen lernen. Nauczanie i uczenie się języków obcych. Gdańsk: Wydawnictwo Uniwersytetu Gdańskiego, s. 71-84.

Rost-Roth M . (2010), Kommunikationswissenschaft, (w:) Barkowski H., Krumm

H.-J. (red.), Fachlexikon Deutsch als Fremd- und Zweitsprache. Tübingen, Basel: Francke Verlag, s. 157.

Rozporządzenie M inistra Nauki i Szkolnictwa Wyższego z dnia 25 lipca 2019 r. w sprawie standardu kształcenia przygotowującego do wykonywania zawodu nauczyciela. Dz. U. 2019, poz. 1450.

Rozporządzenie M NiSzW z dnia 17 stycznia 2012 w sprawie standardów kształcenia przygotowującego do wykonywania zawodu nauczyciela. Dz. U. 2012, poz. 131.

Röbken H., Wetzel K. (2016), Qualitative und quantitative Forschungsmethoden. Oldenburg: Carl von Ossietzky Universität Oldenburg.

Ruthemann U. (2002), Psychologische Vorbereitung zukünftiger Lehrpersonen. „Beiträge zur Lehrerinnen- und Lehrerbildung“, nr 20, s. 319-328. 
Salewski Ch., Renner B. (2009), Differentielle und Persönlichkeitspsychologie. M ünchen: Ernst Reinhardt Verlag.

Schneider W., Lindenberger, U. (red.) (2012), Entwicklungspsychologie. Weinheim, Basel: Beltz Verlag.

Schramm K. (2016), Empirische Forschung, (w:) Caspari D., Clippel F., Legutke K., Schramm K. (red.), Forschungsmethoden in der Fremdsprachendidaktik. Tübingen: Narr Francke Attempto Verlag, s. 49-58.

Skowronek B. (2013), Glottodidaktik und Fremdsprachenunterricht in der Diskussion. Poznań: Wydawnictwo Naukowe UAM .

Skowronek B. (2014), Glottodidaktik und ihre Entwicklung. "Glottodidactica“, $\mathrm{nr} \mathrm{XLI/1,} \mathrm{s.} \mathrm{21-33.}$

Spering M., Schmidt T. (2017), Allgemeine Psychologie 1 kompakt. Weinheim, Basel: Psychologie Verlagsunion in der Verlagsgruppe Beltz.

Wilczyńska W., M ichońska-Stadnik A. (2010), M etodologia badań w glottodydaktyce. Kraków: Wydawnictwo AVALON.

Woolfolk A. (2014), Pädagogische Psychologie. Hallbergmoos: Pearson Deutschland.

Wysocka M. (2003), Profesjonalizm w nauczaniu języków obcych. Katowice: Wydawnictwo Uniwersytetu Śląskiego.

Zawadzka-Bartnik E. (2010), Nauczyciel języków obcych i jego niepełnosprawni uczniowie. Kraków: Impuls.

Zawadzka-Bartnik E. (2014), Refleksje o sukcesie z glottodydaktykq w tle, (w:) Karpeta-Peć B., Kucharczyk R., Smuk M., Torenc M. (red.), Wyznaczniki sukcesu nauczyciela i ucznia w glottodydaktyce. Warszawa: Instytut Germanistyki i Instytut Romanistyki Uniwersytetu Warszawskiego, s. 11-25. 
Interdyscyplinarna specyfika kształcenia nauczycieli języków obcych...

\section{Aneks}

\begin{tabular}{|l|l|}
\hline Wybrane treści kształcenia glottopedeutologicznego & Nauki referencyjne \\
\hline Glottodydaktyka a psycho-pedagogika & glottodydaktyka, psychologia, pedagogika \\
\hline Dyscypliny naukowe powiązane z glottodydaktyką & psychologia, glottodydaktyka \\
\hline Podstawowe pojęcia psychologii & psychologia \\
\hline Rozwój dzieci i młodzieży & psychologia, pedagogika, glottodydaktyka \\
\hline Teorie i struktura osobowości & psychologia \\
\hline Percepcja społeczna i wiedza & pedagogika, socjologia, nauki kognitywne \\
\hline Psychologiczne koncepcje człowieka & psychologia \\
\hline Interpretacja zachowań i sytuacji uczniów w szkole & pedagogika, psychologia \\
\hline Edukacja a rozwój & pedagogika, psychologia \\
\hline Szkoła jako instytucja edukacyjna & pedagogika, psychologia \\
\hline Zawód nauczyciela & $\begin{array}{l}\text { pedagogika, psychologia, prawo oświatowe, } \\
\text { glottodydaktyka }\end{array}$ \\
\hline Komunikacja i kultura języka & $\begin{array}{l}\text { psychologia, pedagogika, socjologia, glotto- } \\
\text { dydaktyka, nauki o komunikacji }\end{array}$ \\
\hline Poznawanie uczniów & pedagogika, psychologia \\
\hline Pojęcia normy i patologii & pedagogika, psychologia \\
\hline Profilaktyka w szkole & pedagogika, psychologia \\
\hline
\end{tabular}

Tab. 3: Moduł 2 - Komponent modułu 2.1. - Ogólne przygotowanie psychologicznopedagogiczne - Przedmiot: Psychopedagogika (wykład) - Studia I stopnia - Instytut Germanistyki Uniwersytetu Warszawskiego (zestawienie własne).

\begin{tabular}{|l|l|}
\hline Wybrane treści kształcenia glottopedeutologicznego & Nauki referencyjne \\
\hline Uczniowie na 3. i 4. etapie edukacyjnym & psychologia, pedagogika \\
\hline $\begin{array}{l}\text { Rozwój dzieci i młodzieży; modele i fazy rozwoju; wyja- } \\
\text { śnienie pojęcia okresu dojrzewania; wczesna dorosłość. }\end{array}$ & psyogia, pedagogika \\
\hline $\begin{array}{l}\text { Rozwój fizyczny, motoryczny i psychoseksualny nastolat- } \\
\text { ków; zmiany ciała w okresie dojrzewania; dojrzałość fi- } \\
\text { zyczna }\end{array}$ & \\
\hline $\begin{array}{l}\text { Rozwój poznawczy nastolatków; funkcjonowanie pedagogika, glottodydaktyka } \\
\text { mięci; uczenie się w okresie dojrzewania }\end{array}$ & psychologia, pedagogika \\
\hline $\begin{array}{l}\text { Rozwój emocjonalny nastolatków; zmiany psycholo- } \\
\text { giczne w okresie dojrzewania; dojrzałość emocjonalna; toż- } \\
\text { samość }\end{array}$ & psychologia, pedagogika \\
\hline $\begin{array}{l}\text { Rozwój społeczny młodych ludzi; dojrzałość społeczna; } \\
\text { identyfikacja z nowymi rolami społecznymi }\end{array}$ & psychologia, pedagogika, socjologia \\
\hline $\begin{array}{l}\text { Etyczny rozwój młodych ludzi; dorosłość; formowanie } \\
\text { osobistego stylu życia }\end{array}$ & psychologia, pedagogika, aksjologia socjologia \\
\hline $\begin{array}{l}\text { Kontakty społeczne ucznia; grupa rówieśników; pozycja } \\
\text { społeczna w grupie; znaczenie grupy; przyjaźń i miłość }\end{array}$ & pedagogika, psychologia, socjologia \\
\hline $\begin{array}{l}\text { Konflikty z rówieśnikami, rodzicami, wychowawcami; } \\
\text { idole i autorytety; zmiana autorytetów; kryzys autory- } \\
\text { tetu nauczycieli i rodziców; rozwiązywanie konfliktów }\end{array}$ & \\
\hline $\begin{array}{l}\text { Opór w okresie dojrzewania i jego funkcje; uzależnienia; } \\
\text { agresja; przemoc; grupy nieformalne; sekty; subkultury; } \\
\text { wykluczenia; akceptacja }\end{array}$ & pedagogika, psychologia, socjologia \\
\hline $\begin{array}{l}\text { Nowa szkoła; dostosowanie do nowej szkolnej rzeczywi- } \\
\text { stości; wybór przedmiotów maturalnych; wybór kariery; } \\
\text { pragnienie uznania; ambicje; motywacje }\end{array}$ & \\
\hline
\end{tabular}


Zaburzenia w okresie dojrzewania; wahania nastroju; psychologia, pedagogika, pedagogika specjalna depresja; zaburzenia zachowania; profilaktyka

Pozytywne wspieranie młodych ludzi; pozytywne opinie psychologia, pedagogika, komunikacja, aksjologia nauczycieli i rodziców

Tab. 4: Moduł 2 - Komponent modułu 2.2. - Przygotowanie psychologiczno-pedagogiczne do nauczania w szkołach ponadpodstawowych - Przedmiot: Aplikacje psychologiczno-pedagogiczne w glottodydaktyce 1 - III etap edukacyjny (ćwiczenia) - Studia II stopnia - Instytut Germanistyki Uniwersytetu Warszawskiego (zestawienie własne).

\begin{tabular}{|l|l|}
\hline Wybrane treści kształcenia & Nauki referencyjne \\
\hline Dydaktyka jako subdyscyplina pedagogiki & $\begin{array}{l}\text { dydaktyka ogólna, pedagogika, glottody- } \\
\text { daktyka }\end{array}$ \\
\hline $\begin{array}{l}\text { Szkoła jako instytucja promująca rozwój jednostki i społeczeń- } \\
\text { stwa }\end{array}$ & dydaktyka ogólna, pedagogika \\
\hline Proces nauczania i uczenia się & $\begin{array}{l}\text { dydaktyka ogólna, psychologia, pedago- } \\
\text { gika, glottodydaktyka } \\
\text { dydaktyka ogólna, prawo oświatowe }\end{array}$ \\
\hline System edukacji & $\begin{array}{l}\text { dydaktyka ogólna, pedagogika, psycholo- } \\
\text { gia, glottodydaktyka }\end{array}$ \\
\hline Klasa szkolna jako środowisko edukacyjne & $\begin{array}{l}\text { dydaktyka ogólna, pedagogika, edukacja } \\
\text { specjalna, psychologia, glottodydaktyka }\end{array}$ \\
\hline $\begin{array}{l}\text { Projektowanie działań edukacyjnych w kontekście specjalnych } \\
\text { potrzeb edukacyjnych i specjalnych umiejętności uczniów }\end{array}$ & $\begin{array}{l}\text { dydaktyka ogólna, pedagogika, psycholo- } \\
\text { gia, glottodydaktyka }\end{array}$ \\
\hline Diagnoza, kontrola i ocena efektów edukacyjnych & $\begin{array}{l}\text { dydaktyka ogólna, glottodydaktyka, nauki } \\
\text { o komunikacji }\end{array}$ \\
\hline Język (obcy) jako narzędzie pracy nauczyciela &
\end{tabular}

Tab. 5: M oduł 3 - Komponent modułu 3.1. - Przygotowanie dydaktyczne - Przedmiot: Podstawy dydaktyki (wykład) - Studia I stopnia - Instytut Germanistyki Uniwersytetu Warszawskiego (zestawienie własne).

\begin{tabular}{|c|c|c|c|c|c|}
\hline & \multirow{2}{*}{\begin{tabular}{|l|} 
Kształcenie \\
ogólno-aka- \\
demickie \\
(obszar teo- \\
retyczno- \\
naukowy)
\end{tabular}} & \multirow{2}{*}{\begin{tabular}{|c|} 
Interdyscy- \\
plinarne \\
projekty ba- \\
dawcze \\
(obszar em- \\
piryczny)
\end{tabular}} & \multirow{2}{*}{\begin{tabular}{|c|} 
Specjali- \\
zacja \\
(obszar \\
naukowo- \\
empir.)
\end{tabular}} & \multicolumn{2}{|c|}{$\begin{array}{c}\text { Kształcenie zawodowe } \\
\text { (obszar teoretyczno- } \\
\text { praktyczny) }\end{array}$} \\
\hline & & & & \begin{tabular}{|c|} 
Upraw- \\
nienia do \\
nauczania \\
j. niem. I- \\
II etap ed. \\
\end{tabular} & $\begin{array}{l}\text { Uprawnie- } \\
\text { nia do nau- } \\
\text { czania j. } \\
\text { niem. III- IV } \\
\text { etap ed. }\end{array}$ \\
\hline \multicolumn{6}{|c|}{ I rok I st. } \\
\hline Psychopedagogika (w.) & tak & tak & & tak & \\
\hline Psychopedagogika (w.) & tak & tak & & tak & \\
\hline Psychopedagogika (ćw.) & tak & tak & & tak & \\
\hline Psychopedagogika - I etap edukacyjny & tak & tak & & tak & \\
\hline Psychopedagogika - II etap edukacyjny & tak & tak & & tak & \\
\hline $\begin{array}{l}\text { Praktyka psychologiczno-pedagogiczna - I i II etap } \\
\text { edukacyjny }\end{array}$ & & tak & & tak & \\
\hline \multicolumn{6}{|c|}{ II rok I st. } \\
\hline Podstawy dydaktyki (w.) & tak & tak & & tak & \\
\hline Glottodydaktyka (w.) & tak & tak & & tak & \\
\hline Glottodydaktyka (ćw.) & tak & tak & & tak & \\
\hline
\end{tabular}


Interdyscyplinarna specyfika kształcenia nauczycieli języków obcych...

\begin{tabular}{|c|c|c|c|c|c|}
\hline Glottodydaktyka (ćw.) & tak & tak & & tak & \\
\hline $\begin{array}{l}\text { Wstępna praktyka dydaktyczna - } \\
\text { I i II etap edukacyjny }\end{array}$ & & tak & & tak & \\
\hline $\begin{array}{l}\text { Zasadnicza praktyka dydaktyczna - } \\
\text { I i ll etap edukacyjny }\end{array}$ & & tak & & tak & \\
\hline \multicolumn{6}{|c|}{ III rok I st. } \\
\hline Wczesna edukacja językowa & tak & tak & & & \\
\hline Badania nad kompetencją międzykulturową & tak & tak & & & \\
\hline \multicolumn{6}{|l|}{ (1) } \\
\hline Nowe prądy w glottodydaktyce & tak & tak & tak & & \\
\hline Nowe prądy w glottodydaktyce & tak & tak & tak & & \\
\hline Zajęcia specjalizacyjne & tak & tak & tak & & \\
\hline Zajęcia specjalizacyjne & tak & tak & tak & & \\
\hline Seminarium magisterskie & tak & tak & tak & & \\
\hline Seminarium magisterskie & tak & tak & tak & & \\
\hline $\begin{array}{l}\text { Psychologiczno-pedagogiczny projekt badawczy } \\
\text { w glottodydaktyce }\end{array}$ & tak & tak & tak & tak & tak \\
\hline $\begin{array}{l}\text { Aspekty psychologiczno-ped. w glottodydaktyce } 1 \\
\text { - I i ll etap edukacyjny }\end{array}$ & tak & tak & tak & tak & \\
\hline $\begin{array}{l}\text { Aspekty psychologiczno-ped. w glottodydaktyce } 2 \\
\text { - I i ll etap edukacyjny }\end{array}$ & tak & tak & tak & tak & \\
\hline $\begin{array}{l}\text { Aplikacje psycholog.-pedagog. w glottodydaktyce } \\
\text { 1 - III i IV etap edukacyjny }\end{array}$ & tak & tak & tak & & tak \\
\hline $\begin{array}{l}\text { Aplikacje psycholog.-pedagog. w glottodydaktyce } \\
2 \text { - III i IV etap edukacyjny }\end{array}$ & tak & tak & tak & & tak \\
\hline $\begin{array}{l}\text { Wybrane konteksty nauczania języków obcych } 1 \text { - } \\
\text { I i ll etap edukacyjny }\end{array}$ & tak & tak & tak & tak & \\
\hline $\begin{array}{l}\text { Praktyka psychologiczno-pedagogiczna - III i IV } \\
\text { etap edukacyjny }\end{array}$ & & tak & & & tak \\
\hline \multicolumn{6}{|c|}{ II rok II st. } \\
\hline Seminarium magisterskie & tak & tak & tak & & \\
\hline Seminarium magisterskie & tak & tak & tak & & \\
\hline $\begin{array}{l}\text { Wybrane konteksty nauczania języków obcych } 2 \text { - } \\
\text { I i ll etap edukacyjny }\end{array}$ & tak & tak & tak & tak & \\
\hline $\begin{array}{l}\text { Wybrane konteksty nauczania języków obcych } 3 \text { - } \\
\text { I ill etap edukacyjny }\end{array}$ & tak & tak & tak & tak & \\
\hline Podstawowe konteksty nauczania języków obcych & tak & tak & tak & tak & tak \\
\hline $\begin{array}{l}\text { Glottodydaktyczne kompetencje nauczyciela } 1 \text { - } \\
\text { III i IV etap edukacyjny }\end{array}$ & tak & tak & tak & & tak \\
\hline $\begin{array}{l}\text { Glottodydaktyczne kompetencje nauczyciela } 2 \text { - } \\
\text { III i IV etap edukacyjny }\end{array}$ & tak & tak & tak & & tak \\
\hline $\begin{array}{l}\text { Glottodydaktyczne kompetencje nauczyciela } 3 \text { - } \\
\text { III i IV etap edukacyjny }\end{array}$ & tak & tak & tak & & tak \\
\hline $\begin{array}{l}\text { Wstępna praktyka dydaktyczna - III i IV etap edu- } \\
\text { kacyjny }\end{array}$ & & tak & & & tak \\
\hline $\begin{array}{l}\text { Zasadnicza praktyka dydaktyczna - III i IV etap } \\
\text { edukacyjny }\end{array}$ & & tak & & & tak \\
\hline
\end{tabular}

Tab. 6: Glottopedeutologiczne kształcenie nauczycieli języka niemieckiego - wykaz przedmiotów oferowanych w Zakładzie Glottodydaktyki Instytutu Germanistyki Uniwersytetu Warszawskiego - stan na dzień 27.03.2018 (zestawienie własne). 